\title{
Hypoxic and Ischemic Hypoxia Exacerbate Brain Injury Associated with Metabolic Encephalopathy in Laboratory Animals
}

\author{
Zinaida S. Vexler, ${ }^{\star}$ J. Carlos Ayus, ${ }^{\star}$ Timothy P. L. Roberts, ${ }^{\star}$ Cosmo L. Fraser, ${ }^{3}$ John Kucharczyk, * and Allen I. Arieff \\ *Neuroradiology Section, University of California at San Francisco, San Francisco, California 94143; ${ }^{*}$ Department of Medicine, Baylor \\ College of Medicine, Houston, Texas 77024; and ${ }^{\S}$ Geriatrics Section, Department of Medicine, Veteran's Affairs Medical Center and \\ University of California at San Francisco, San Francisco, California 94121
}

\begin{abstract}
Hypoxemia is a major comorbid factor for permanent brain damage in several metabolic encephalopathies. To determine whether hypoxia impairs brain adaptation to hyponatremia, worsening brain edema, we performed in vitro and in vivo studies in cats and rats with hyponatremia plus either ischemic or hypoxic hypoxia. Mortality with hypoxic hypoxia was $0 \%$; with hyponatremia, $22 \%$; and with hyponatremia + hypoxia, $100 \%$. Hyponatremia in cats produced brain edema, with a compensatory decrease of brain sodium. Ischemic hypoxia also resulted in brain edema, but with elevation of brain sodium. However, when ischemic hypoxia was superimposed upon hyponatremia, there was elevation of brain sodium with further elevation of water. Outward sodium transport in cat cerebral cortex synaptosomes was measured via three major pathways through which brain osmolality can be decreased. After hyponatremia, sodium transport was significantly altered such that brain cell osmolality would decrease: $44 \%$ increase in $\mathrm{Na}^{+}-\mathrm{K}^{+}$-ATPase transport activity (ouabain inhibitable); $26 \%$ decrease in amiloride-sensitive sodium uptake. The change in veratridine-stimulated sodium uptake was not significant $(P>0.05)$. When ischemic hypoxia was superimposed upon hyponatremia, all of the cerebral adaptive changes induced by hyponatremia alone were eliminated. Thus, hypoxia combined with hyponatremia produces a major increase in brain edema and mortality, probably by eliminating the compensatory mechanisms of sodium transport initiated by hyponatremia that tend to minimize brain swelling. (J. Clin. Invest. 1994. 93:256-264.) Key words: metabolic encephalopathy $\bullet$ hypoxia $\bullet$ hyponatremia $\bullet$ synaptosomes - sodium transport
\end{abstract}

\section{Introduction}

Brain dysfunction in the absence of obvious structural abnormalities may result from endogenous metabolic abnormalities, such as hypoglycemia, hyper- and hyponatremia, hypoxia or uremia, or from exposure to exogenous intoxicants, such as ethyl alcohol, cocaine, or carbon monoxide (1). Frequently, metabolic encephalopathies are produced by multiple causes, such as ethanol intoxication with phosphate depletion (1), hy-

This work was presented in part at the annual meeting of the American Society for Clinical Investigation, Baltimore, MD, May 1-3, 1992 (Clin. Res. 1992. 40:306a Abstr.).

Address correspondence to Dr. J. Carlos Ayus, no. 4 Brompton Court, Houston, TX 77024.

Received for publication 26 February 1993 and in revised form 3 August 1993.

The Journal of Clinical Investigation, Inc.

Volume 93, January 1994, 256-264 pernatremia with hepatic encephalopathy (2), hyponatremia with hypoxia (3), and carbon monoxide exposure with hypoxia (4).

Hyponatremia and hypoxia are among the most common metabolic abnormalities seen in a general hospital population (5-7). Among patients with hyponatremia, 1\% develop encephalopathy, and of these, $\sim 20 \%$ die or suffer permanent brain damage $(3,7)$. Death in such patients is largely the result of brain edema, which, if the brain is unable to adapt, often leads to cerebral herniation $(3,7)$. Recent studies from our laboratories in $>100$ patients with hyponatremic encephalopathy have demonstrated that systemic hypoxemia is a major factor leading to permanent brain damage $(3,7,8)$. With hypoxic hypoxia, there is decreased oxygen availability to the entire brain, with increased blood flow (9). With ischemic hypoxia, both oxygen availability and blood flow are impaired (9).

The brain adapts to hyponatremia largely by extruding monovalent cations, such as sodium, to decrease brain cell osmolality and reduce the amount of cerebral edema $(10,11)$. Transport of sodium from the brain is regulated primarily by oxygen-requiring pathways (12). Hypoxia alone can lead to cerebral edema (6), and hypoxia in the presence of other metabolic encephalopathies often worsens the degree of brain injury (13). These factors suggest that hypoxia may impair adaptation of the brain to metabolic encephalopathies by inhibition of sodium transport.

\section{Methods}

Animal models. In adult rats of both sexes acute hyponatremia was induced by subcutaneous injection of $1 \mathrm{U}$ of arginine vasopressin in oil and intraperitoneal injection of $10 \%$ body weight of $140 \mathrm{mM}$ glucose/ $\mathrm{H}_{2} \mathrm{O}$ (14).

Hypoxic hypoxia (9) was induced by having rats breath either $90 \%$ nitrogen, $10 \%$ oxygen, or room air for $3 \mathrm{~h}$ in an airtight chamber. After, arterial blood samples were collected and arterial blood $\mathrm{pH}, \mathrm{pO}_{2}$, $\mathrm{pCO}_{2}$, and bicarbonate and plasma sodium were measured. Four experimental groups of rats were established: control (arterial $\mathrm{pO}_{2}, 97 \pm 3$ $\mathrm{mm} \mathrm{Hg} ; \mathrm{pCO}_{2}, 38 \pm 2 \mathrm{~mm} \mathrm{Hg}$ ), $n=10$; hypoxia (arterial $\mathrm{pO}_{2}, 35 \pm 3$ $\mathrm{mm} \mathrm{Hg} ; \mathrm{pCO}_{2}, 23 \pm 2 \mathrm{~mm} \mathrm{Hg}$ ) with normonatremia (plasma sodium, $140 \mathrm{mM}$ ),$n=7$; normoxia (arterial $\mathrm{pO}_{2}, 92 \pm 4 \mathrm{~mm} \mathrm{Hg} ; \mathrm{pCO}_{2}, 39 \pm 3$ $\mathrm{mm} \mathrm{Hg}$ ) with hyponatremia (plasma sodium, $106 \mathrm{mM}$ ), $n=12$; and hypoxia ( $\mathrm{pO}_{2}, 37 \pm 3 \mathrm{~mm} \mathrm{Hg}$; $\mathrm{pCO}_{2}, 26 \pm 2 \mathrm{~mm} \mathrm{Hg}$ ) with hyponatremia (plasma sodium, $108 \mathrm{mM}$ ), $n=9$.

Experiments were performed in two groups of female cats: normal controls ( six animals) and acute hyponatremia for $3 \mathrm{~h}$ (eight animals). Additionally, unilateral middle cerebral artery (MCA) ${ }^{1}$ was induced in each group. Thus, four subgroups were created: normal controls;

1. Abbreviations used in this paper: ADC, apparent diffusion coeffcient; MCA, middle cerebral artery; MRI, magnetic resonance imaging. 
hyponatremic normoxic animals; normonatremic cats with focal ischemia (ischemic hypoxia); and hyponatremic cats in which focal ischemia for $90 \mathrm{~min}$ was induced after $90 \mathrm{~min}$ of induction of hyponatremia.

Animals weighing $2.5-4.0 \mathrm{~kg}$ were intravenously anesthetized with $35 \mathrm{mg} / \mathrm{kg}$ sodium pentobarbital. Femoral vein and artery catheters were placed for blood pressure monitoring and administration of the contrast agent. Six cats were then placed in the magnetic resonance imaging (MRI) unit for collecting diffusion-weighted and contrast-enhanced echo-planar images in normal animals. Then animals were removed from the magnet for the induction of hyponatremia and/or ligation of the MCA. After ligation of the MCA, cats were immediately placed in the magnet. During whole MRI experiment cats were maintained with $1-2 \%$ isoflurane in $30 \%$ oxygen, $70 \%$ nitrous oxide, and mechanically ventilated through an endotracheal tube. Plasma sodium and arterial blood pH, $\mathrm{pO}_{2}, \mathrm{pCO}_{2}$, and bicarbonate were monitored (15).

Acute hyponatremia was induced in cats by subcutaneous injection of $1 \mathrm{U}$ of arginine vasopressin in oil and intraperitoneal injection of $12.5 \%$ body weight of $140 \mathrm{mM}$ glucose $/ \mathrm{H}_{2} \mathrm{O}$, followed by two subcutaneous injections of $0.5 \mathrm{U}$ of arginine vasopressin in water every $30 \mathrm{~min}$. Plasma sodium was measured every $30 \mathrm{~min}$. The serum sodium was $123 \pm 3 \mathrm{mM}$ after $3 \mathrm{~h}$, which is $30 \mathrm{mM}$ below the control value of $153 \pm 1$ $\mathrm{mM}(P<0.01)$ of the normonatremic cats.

Ischemic hypoxia was produced by unilateral ligation of the MCA for $90 \mathrm{~min}$, as previously described $(16,17)$. After ligation of the MCA, cats were immediately placed in the magnet. At the end of the imaging experiment, they were killed, and brain tissue samples were quickly dissected from ischemic tissue in the right hemisphere (areas were defined by contrast-enhanced MRI) and from the corresponding areas of the contralateral hemisphere. Most of the tissue was immediately placed in the isolation media ( $320 \mathrm{mM}$ sucrose, $0.2 \mathrm{mM} \mathrm{K-EDTA,} 5$ $\mathrm{mM}$ Tris- $\mathrm{HCl}, \mathrm{pH} 7.40$ ) to be used for isolation of synaptosomes. The rest of the tissue from the selected regions of the brains was used for the water and electrolytes analysis.

MRI protocol. To investigate the effect of hyponatremia, ischemic hypoxia, or a combination of those on the magnitude of the apparent diffusion coefficient (ADC) and cerebral perfusion, we used MRI. Imaging experiments were performed on a 2 Tesla Omega CSI system (Bruker Instruments, Fremont, CA) equipped with Acustar S- 150 selfshielded gradients $(20 \mathrm{G} / \mathrm{cm}, 15 \mathrm{~cm}$ i.d.). A home-built $9-\mathrm{cm}$ i.d. volume birdcage radio frequency coil was used in all studies. Stejskal-Tanner diffusion sensitizing gradients $(18)$ of strengths up to $11 \mathrm{G} / \mathrm{cm}$ were used to obtain diffusion-weighted images with " $b$ values" in the range of 0 to $2,442 \mathrm{~s} / \mathrm{mm}^{2}$.

A net restriction of water proton movement, due to an increased proportion of confined intracellular fluid, and thus the location of cytotoxic brain edema, was determined using diffusion-weighted MRI experiments as previously described $(19,20)$. The ADC has been proposed to be a marker of cytotoxic edema, as it decreases progressively as water shifts from the extracellular to intracellular space $(19,20)$. Spatial "maps" of the ADC (Fig. $1 A$ ) were generated by pixel-by-pixel logarithmic regression analysis of the diffusion-weighted images, assuming an exponential loss of signal dependent on the product of the $A D C$ and the image $b$ value (21):

$S \sim \exp (-b D)$

where $D$ represents the ADC.

Regions of interest for the quantitative assessment of the ADC in each of the subgroups were chosen in cortical regions and included MCA vascular territory.

16 contrast-enhanced high-speed echo-planar images (echo time, $80 \mathrm{~ms}$ ) were acquired at 2-s intervals after bolus intravenous administration of $0.25 \mathrm{mmol} / \mathrm{kg}$ of sprodiamide injection, which contained $500 \mathrm{mM}$ of a magnetic susceptibility contrast agent, dysprosium-diethylenetriaminepentaacetic acid-bis [methylamide] (DyDTPA-BMA) (Nycomed Salutar, Inc. and Sterling Winthrop) (16). The signal intensity variations before, during, and after the administration of sprodiamide injection were compared in the region of the nonoccluded MCA in the left hemisphere and the occluded right hemisphere in terms of transit of the contrast agent. A transient loss of the signal intensity was seen in the hemisphere contralateral to the occluded MCA during the transit of the contrast agent bolus through the brain. No such signal loss was observed in regions ipsilateral to MCA occlusion, indicating no transit of the contrast agent and consequently demarcating perfusion deficits in the vascular territory of the occluded MCA $(16,20)$.

Isolation of synaptosomes. Synaptosomes were isolated from brain regions that were selected on the basis of observed perfusion deficits on MRI perfusion-sensitive imaging (Fig. $1 B)(20,22)$ and diffusionweighted images (Fig. $1 A)(19,20)$, and from the corresponding areas of the contralateral hemisphere in each individual animal. Synaptosomes were extracted from the cerebral cortex of normal, hyponatremic normoxic, normonatremic ischemic, and hyponatremic ischemic cat brain.

Synaptosomes were prepared as previously described in our laboratory (23). In brief, brain tissue was minced and rinsed three times with $5-10 \mathrm{ml}$ of the ice-cold isolation media $(320 \mathrm{mM}$ sucrose, $0.2 \mathrm{mM}$ $\mathrm{K}$-EDTA, $5 \mathrm{mM}$ Tris- $\mathrm{HCl}, \mathrm{pH} 7.40$ ). 20 volumes of isolation media per $1 \mathrm{~g}$ of tissue was added, and the extract then was poured into a Dounce homogenizer and homogenized. The suspension was spun at $1,300 \mathrm{~g}$ for $8 \mathrm{~min}$ in a centrifuge (J21 B; Beckman Instrs., Inc., Fullerton, CA). The supernatant then was spun at $18,000 \mathrm{~g}$ for $10 \mathrm{~min}$ to obtain a synaptosomal/mitochondrial pellet. The pellet was resuspended in isolation media by homogenization and an aliquot was layered on a discontinuous Ficoll gradient. We modified the previously described methods. (23) using 7.2 and $11.5 \%$ Ficoll gradients. The gradient then was ultracentrifuged at $100,000 \mathrm{~g}$ for $70 \mathrm{~min}$ using an ultracentrifuge ( L-880, SW28 rotor; Beckman Instrs., Inc.). Synaptosomes that were located between 7.2 and $11.5 \%$ layers were removed by suction and homogenized in $\sim 20 \mathrm{ml}$ of ice-cold isolation media and spun at $18,000 \mathrm{~g}$ for $10 \mathrm{~min}$. Pellets were resuspended in $7.5 \mathrm{ml}$ of the isolation media, homogenized, and stored as $0.5-\mathrm{ml}$ aliquots at $-80^{\circ} \mathrm{C}$. At the time of transport studies, an aliquot was removed and allowed to thaw at room temperature.

Transport activity of $\mathrm{Na}^{+}-\mathrm{K}^{+}-$ATPase. The kinetic characteristics of rubidium uptake in synaptosomes have been shown to be similar to those for potassium uptake (23), and thus, rubidium $\left({ }^{86} \mathrm{Rb}\right)$ uptake with or without ouabain was used for the in vitro determination of potassium transport via $\mathrm{Na}^{+}-\mathrm{K}^{+}-\mathrm{ATPase}$ in these studies. Data on sodium transport via $\mathrm{Na}^{+}-\mathrm{K}^{+}$-ATPase could be obtained based on rubidium uptake because: $(a)$ rubidium is an adequate substitute for potassium for an estimation of the potassium transport via $\mathrm{Na}^{+}-\mathrm{K}^{+}$-ATPase, as the permeability of the synaptosomal membrane for rubidium is the same as that for potassium $(23,24)$, and rubidium is relatively more stable than radiolabeled potassium; and $(b)$ the stoichiometry of sodium/potassium exchange by $\mathrm{Na}^{+}-\mathrm{K}^{+}$-ATPase is well defined. Previous observations $(12,23)$ from our laboratory showed that maximum uptake of rubidium could be expected after $5 \mathrm{~min}$. So, we chose this time interval in these studies.

Aliquots of synaptosomes were preloaded with $\left(\mathrm{Na}^{+}\right)$by incubation in four times its volume of preequilibrium media ([ in $\mathrm{mM}] \mathrm{NaCl}$,

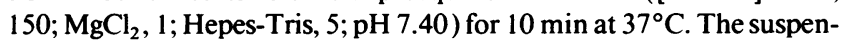
sion then was centrifuged at $18,000 \mathrm{~g}$ for $6 \mathrm{~min}$, and the pellet resuspended in $400-500 \mu \mathrm{l}$ of preequilibrium media $(12,23)$. The reaction of the ${ }^{86} \mathrm{Rb}$ uptake was initiated with the addition of $5 \mu$ l of synaptosome suspension ( $\sim 20-30 \mu \mathrm{g}$ protein) to $95 \mu \mathrm{l}$ uptake media ([in $\mathrm{mM}$ ] choline chloride, $140 ; \mathrm{MgCl}_{2}$, 5 ; EGTA, $0.2 ; \mathrm{KCl}, 1$; Hepes-Tris, 5 ; $\mathrm{pH} 7.40,0.5 \mu \mathrm{Ci}^{86} \mathrm{Rb} 70,000 \mathrm{cpm}$ ) at $25^{\circ} \mathrm{C}$. After $5 \mathrm{~min}$ of incubation, uptake was stopped by adding $2.5 \mathrm{ml}$ ice-cold choline chloride $(150 \mathrm{mM})$ to the transport mixture. The reaction mixture was immediately vacuum filtered through a $0.45-\mu \mathrm{m}$ pore cellulose acetate membrane. The zero time point ${ }^{86} \mathrm{Rb}$ uptake (nonspecific binding) was obtained by adding $5 \mu$ l protein suspension to $95 \mu \mathrm{l}$ uptake media combined with $2.5 \mathrm{ml}$ ice-cold choline chloride $(150 \mathrm{mM})$. This value was subtracted from the 5-min time point to obtain the transport value of ${ }^{86} \mathrm{Rb}$. Each probe was done in triplicate. The same procedure was done using $2.5 \mathrm{mM}$ ouabain in the uptake media. Mean of the ${ }^{86} \mathrm{Rb}$ uptake 
with ouabain was subtracted from the mean without ouabain for each individual experiment.

Veratridine-stimulated sodium uptake. Sodium uptake with or without veratridine $\mathrm{HCl}(50 \mu \mathrm{M})$ was measured in synaptosomes preloaded with potassium ([in $\mathrm{mM}] \mathrm{KCl}, 150 ; \mathrm{MgCl}_{2}, 1$; Hepes-Tris, 5; $\mathrm{pH} 7.40)$ (23) and incubated in four volumes of this preequilibrium media for $10 \mathrm{~min}$ at $37^{\circ} \mathrm{C}$. The suspension was then centrifuged at $18,000 \mathrm{~g}$ for $6 \mathrm{~min}$, and the pellet was resuspended in $400-500 \mu \mathrm{l}$ of preequilibrium media. The reaction was initiated at $25^{\circ} \mathrm{C}$ with the addition of $5 \mu \mathrm{l}$ of synaptosome suspension ( $\sim 20-30 \mu \mathrm{g}$ protein ) to 95 $\mu$ l uptake media ([ in $\mathrm{mM}$ ] choline chloride, $140 ; \mathrm{MgCl}_{2}, 5$; EGTA, 0.2; $\mathrm{NaCl}, 1$; Hepes-Tris, 5 ; pH 7.40, $\left.5.0 \mu \mathrm{Ci}^{22} \mathrm{Na} ; \sim 5 \times 10^{5} \mathrm{cpm}\right)$. After 5 min, uptake was terminated by adding $2.5 \mathrm{ml}$ ice-cold choline chloride $(150 \mathrm{mM})$. The reaction mixture was immediately vacuum filtered through a $0.45-\mu \mathrm{m}$ pore cellulose acetate membrane. The zero time point $\mathrm{Na}$ uptake was obtained by adding $5 \mu$ l protein suspension to 95 $\mu$ l uptake media combined with $2.5 \mathrm{ml}$ ice-cold choline chloride ( 150 $\mathrm{mM}$ ). Mean of the ${ }^{22} \mathrm{Na}$ uptake without veratridine was subtracted from the mean with veratridine for each individual experiment.

Amiloride-sensitive sodium uptake. Sodium uptake was determined in synaptosomes with or without amiloride (1 mM) (25). An aliquot of synaptosomes was incubated with four volumes of preequilibrium media ([in $\mathrm{mM}] \mathrm{KCl}, 150 ; \mathrm{MgCl}_{2}, 1$; Hepes-Tris, 5 ; $\mathrm{pH} \mathrm{7.40)}$ for $10 \mathrm{~min}$ at $37^{\circ} \mathrm{C}$. The suspension was centrifuged at $18,000 \mathrm{~g}$ for 6 $\mathrm{min}$, and the pellet was resuspended in $400-500 \mu \mathrm{l}$ of preequilibrium media. The reaction was started at $25^{\circ} \mathrm{C}$ with the addition of $5 \mu \mathrm{l}$ of synaptosome suspension ( $\sim 20-30 \mu \mathrm{g}$ protein $)$ to $95 \mu \mathrm{l}$ uptake media ( [in $\mathrm{mM}$ ] choline chloride, $140 ; \mathrm{MgCl}_{2}, 5$; EGTA, $0.2 ; \mathrm{NaCl}, 1$; tetrodotoxin, $1 \times 10^{-3}$; Hepes-Tris, $5 ; \mathrm{pH} 7.40,5.0 \mu \mathrm{Ci}^{22} \mathrm{Na} ; \sim 5 \times 10^{5}$ cpm). After $5 \mathrm{~min}$, uptake was terminated by adding $2.5 \mathrm{ml}$ ice-cold choline chloride $(150 \mathrm{mM})$. The reaction mixture was immediately vacuum filtered through a $0.45-\mu \mathrm{m}$ pore cellulose acetate membrane. The zero time point $\mathrm{Na}$ uptake was obtained by adding $5 \mu \mathrm{l}$ protein suspension to $95 \mu \mathrm{l}$ uptake media combined with $2.5 \mathrm{ml}$ ice-cold choline chloride $(150 \mathrm{mM})$. The ${ }^{22} \mathrm{Na}$ uptake with amiloride was subtracted from the mean without amiloride for each individual experiment.

Protein determination. Protein concentration was determined using the method of Lowry et al. (26) in synaptosome suspension after each ion transport study. Calibration curve was done using bovine serum albumin.

Water and tissue sodium content. Water and sodium content were assessed in brain gray matter, both from cortical areas defined by MRI to have impaired perfusion, and from the corresponding areas of the contralateral hemisphere. The brain water and sodium content were measured as previously described (27). To determine brain water content, we measured the weight of wet brain tissue and then dried the tissue for $72 \mathrm{~h}$ at $105^{\circ} \mathrm{C}$. The difference gave the brain water content. The tissue was then extracted with $1 \mathrm{~N} \mathrm{HNO}_{3}$, and sodium was determined in the supernatant by flame photometry (27).

Statistical analysis. Quantitative data are expressed as mean \pm SE. For animal groups, previous investigations show that for all studies on brain water and electrolytes, and ion transport in synaptosomes, the typical difference between groups is at least $20 \%$ of the control value with SD $<10 \%$ of the control value. Sample size was calculated (28) using a two-tailed $\alpha$ of 0.05 and $\beta$ of 0.20 , and a standardized effect size of $0.80(29)$. Within-group and between-group data were analyzed by ANOVA and, where appropriate, Newman-Keuls tests (28). A probability of $\leq 0.05$ was considered to be statistically significant.

\section{Results}

Rat studies

EFFECTS OF HYPOXIC HYPOXIA AND HYPONATREMIA ON MORTALITY IN RATS

We first evaluated the effects of hyponatremia alone vs. a combination of hyponatremia and hypoxic hypoxia on mortality.
The effects of hypoxic hypoxia, hyponatremia, and a combination of hyponatremia and hypoxic hypoxia on mortality in rats are shown in Fig. 2. In control group 1 rats and in group 2 rats, where the plasma sodium was $140 \mathrm{mM}$ and arterial $\mathrm{pO}_{2} 35 \mathrm{~mm}$ $\mathrm{Hg}$, there was no mortality. In group 3 rats, where the plasma sodium was $106 \mathrm{mM}$ and arterial $\mathrm{pO}_{2} 92 \mathrm{~mm} \mathrm{Hg}$, the mortality was $22 \%$. The group 4 rats had both severe hyponatremia (sodium, $108 \mathrm{mM})$ and hypoxia similar to group $2\left(\mathrm{pO}_{2}, 37 \mathrm{~mm}\right.$ $\mathrm{Hg}$ ), and mortality was $100 \%$. Thus, in the absence of hyponatremia, modest hypoxia did not result in any mortality. Hyponatremia with normal arterial $\mathrm{pO}_{2}$ resulted in a $22 \%$ mortality but the same degree of hyponatremia combined with modest hypoxia resulted in $100 \%$ mortality (Fig. 2 ).

\section{Cat studies}

EFFECTS OF HYPONATREMIA AND ISCHEMIC HYPOXIA ON CAT BRAIN

Since hypoxic hypoxia appeared to have major effects on the outcome in hyponatremic rats, we decided to evaluate the mechanisms by which hypoxia combined with hyponatremia might lead to such an increase in mortality. To determine effects of ischemic hypoxia on brain adaptation to hyponatremia, we measured cat brain water and sodium. Synaptosomes are an appropriate model to investigate cellular (neuronal) mechanisms of brain damage. Synaptosomes are subcellular membrane vesicles derived from brain cortical gray matter that have proven useful in the investigation of metabolic encephalopathies and other disorders of the central nervous system (12, $23,30)$. Synaptosomes contain mitochondria and cytosol, and are similar to neurons in their metabolism (31) and ability to transport ions $(23,30)$. The yield of synaptosomes from individual rat brains is inadequate to evaluate sodium transport via several different pathways. On the other hand, each cat brain hemisphere has adequate tissue for multiple synaptosome studies. We were also interested in creating a model that would enable us to produce encephalopathy selectively in only one hemisphere, thereby allowing us to use the opposite hemisphere as a control in each individual animal.

We have developed a reproducible model of unilateral ischemic hypoxia using unilateral middle cerebral artery ligation in the cat $(16,17)$. Using this model, we were able to compare ischemic brain tissue (hemisphere with unilateral middle cerebral artery ligation) to normal brain tissue (contralateral hemisphere) in the same normonatremic animal. We were also able to compare effects of hyponatremia plus ischemia (hemisphere with unilateral middle cerebral artery ligation) to that of hyponatremia (contralateral hemisphere) in the same hyponatremic cat. In cats with hyponatremia, the plasma sodium fell from the control value of $153 \pm 1$ to $123 \pm 3 \mathrm{mM}$ after $180 \mathrm{~min}$. We induced unilateral ischemia in both normo- and hyponatremic animals as described above.

\section{EFFECTS OF HYPONATREMIA AND ISCHEMIC HYPOXIA ON THE} APPARENT DIFFUSION COEFFICIENT

To assess brain edema associated with hyponatremia, ischemic hypoxia, and combinations of the two, we performed diffusion-weighted MRI using the ADC to demarcate the edema. In nonischemic cerebral tissue, hyponatremia alone caused the ADC to drop from $0.79 \pm 0.02 \times 10^{-5}$ to $0.70 \pm 0.03 \times 10^{-5}$ $\mathrm{cm}^{2} / \mathrm{s}(P<0.03)$ (Fig. 3). The mean ADC values in ischemic (MCA-occluded) brain tissue $\left(0.63 \pm 0.06 \times 10^{-5} \mathrm{~cm}^{2} / \mathrm{s}\right)$ and ischemic/hyponatremic brain $\left(0.62 \pm 0.05 \times 10^{-5} \mathrm{~cm}^{2} / \mathrm{s}\right)$ were significantly lower than in normal brain $(P<0.01)$. 
EFFECTS OF HYPONATREMIA AND ISCHEMIC HYPOXIA ON BRAIN WATER AND ELECTROLYTE CONTENT

To determine effects of ischemic hypoxia on brain adaptation to hyponatremia, we measured cat brain water and electrolytes. In normonatremic cats, $90 \mathrm{~min}$ of MCA occlusion increased water content in the ischemic vascular territory from $389 \pm 10$ to $402 \pm 11 \mathrm{ml} / 100 \mathrm{~g}$ dry tissue $(P>0.05)$ (Fig. $4 A)$. After $3 \mathrm{~h}$ of hyponatremia without ischemia, there was an increase of brain water content to $435 \pm 6 \mathrm{ml} / 100 \mathrm{~g}$ dry tissue, which was significantly greater than the values in both control $(P<0.001)$ and ischemic cat brain $(P<0.025)$. Combined hyponatremia and ischemia caused a further elevation in brain water to $473 \pm 11 \mathrm{ml} / 100 \mathrm{~g}$ dry tissue, which was significantly greater than the value in normal controls $(P<0.001)$, ischemic cats $(P$ $<0.001)$, and hyponatremic animals without ischemia $(P$ $<0.01)$.
Ischemic hypoxia resulted in an increase of brain sodium content from the control value of $262 \pm 14$ to $317 \pm 23 \mathrm{mmol} / \mathrm{kg}$ dry tissue (Fig. $4 B)(P<0.05)$. Hyponatremia without ischemia produced a significant adaptive decrease of brain sodium content from $262 \pm 14$ to $233 \pm 4 \mathrm{mmol} / \mathrm{kg}$ dry tissue $(P$ $<0.05)$. However, the adaptive decrease of brain sodium was not adequate to prevent a significant increase of brain water. The effects of combined hyponatremia and ischemia were similar to the ischemia alone. There was a reversal of the decreased brain sodium observed with hyponatremia alone, 307 \pm 14 $\mathrm{mmol} / \mathrm{kg}$ dry tissue. When ischemia was superimposed on the preexisting hyponatremia, the brain sodium actually increased significantly above the value for hyponatremia alone ( $P$ $<0.001)$, and the control value $(P<0.05)$. This implies that ischemic hypoxia interferes with the $\mathrm{Na}^{+}-\mathrm{K}^{+}$-ATPase pump, so that it cannot be stimulated to extrude sodium, even in the
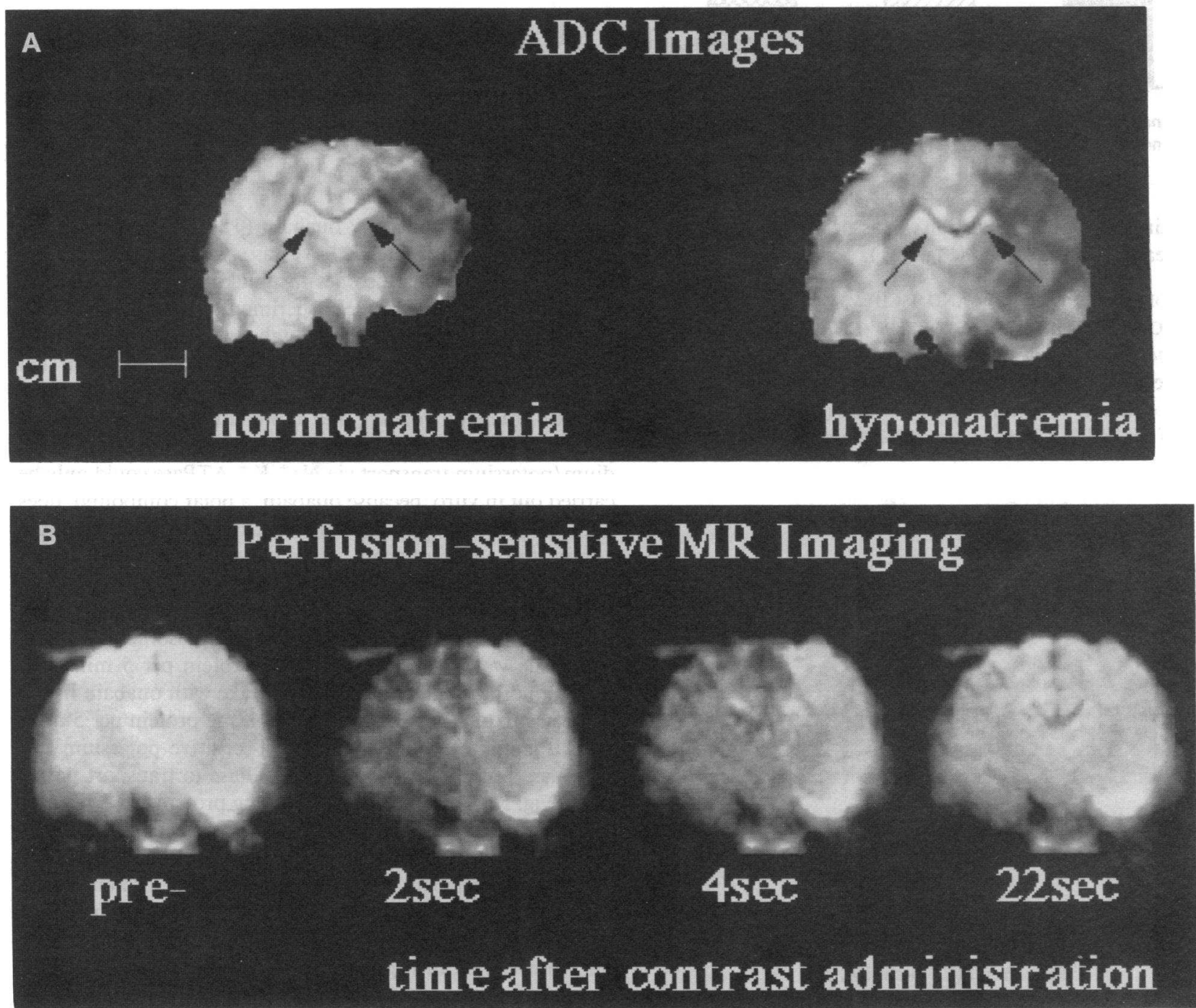

Figure 1. MRI evaluation of the ADC in normonatremic and hyponatremic cats, and areas of perfusion deficits associated with ischemic hypoxia after unilateral MCA occlusion. $(A)$ Spatial images of the ADC in normonatremic (left) and hyponatremic ( right) cats. Progressive compression of lateral cerebral ventricles in ischemic, hyponatremic, and hyponatremic/ischemic brains is shown with arrows. ( $B) 4$ of the 16 high-speed echo-planar images of representative hyponatremic brain (one precontrast and three postcontrast) after bolus intravenous administration of 0.25 $\mathrm{mmol} / \mathrm{kg}$ sprodiamide injection, which contained $500 \mathrm{mM}$ of a magnetic susceptibility contrast agent, DyDTPA-BMA. The signal intensity variations before, during, and after the administration of sprodiamide injection were compared in the region of the nonoccluded MCA in the left hemisphere and the occluded right hemisphere in terms of transit of the contrast agent (persistently bright signal in the right hemisphere represents perfusion deficits in the area of the occluded MCA). 


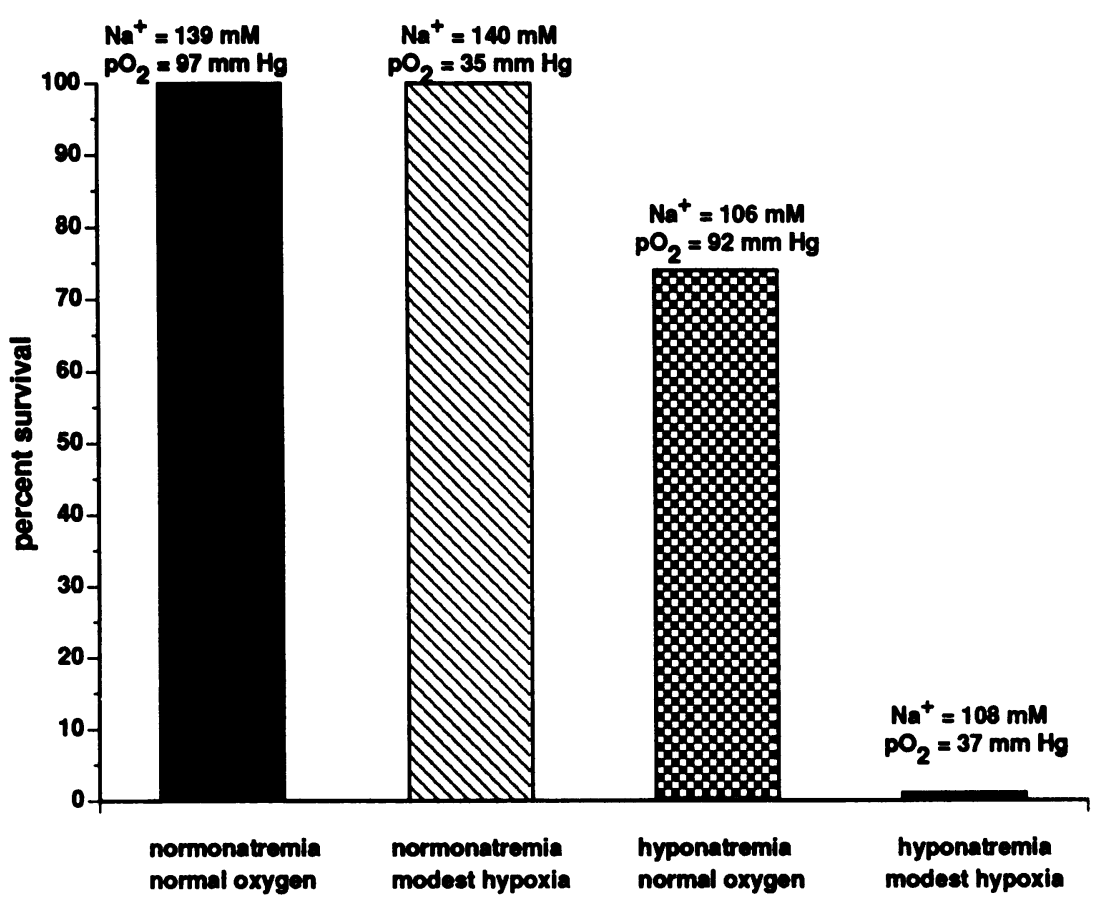

Figure 2. Effect of hypoxic hypoxia, hyponatremia, and hyponatremia combined with hypoxic hypoxia on rat mortality. face of brain edema. This condition was associated with a significant increase in brain edema (Fig. $4 A$ ).

EFFECTS OF HYPONATREMIA AND ISCHEMIC HYPOXIA ON SYNAPTOSOMAL SODIUM TRANSPORT IN CATS

Sodium/potassium transport by $\mathrm{Na}^{+}-\mathrm{K}^{+}-$ATPase in synaptosomes. We then investigated how ischemic hypoxia impaired the ability of the hyponatremic brain to transport sodium. The activity of $\mathrm{Na}^{+}-\mathrm{K}^{+}$-ATPase to pump potassium in exchange

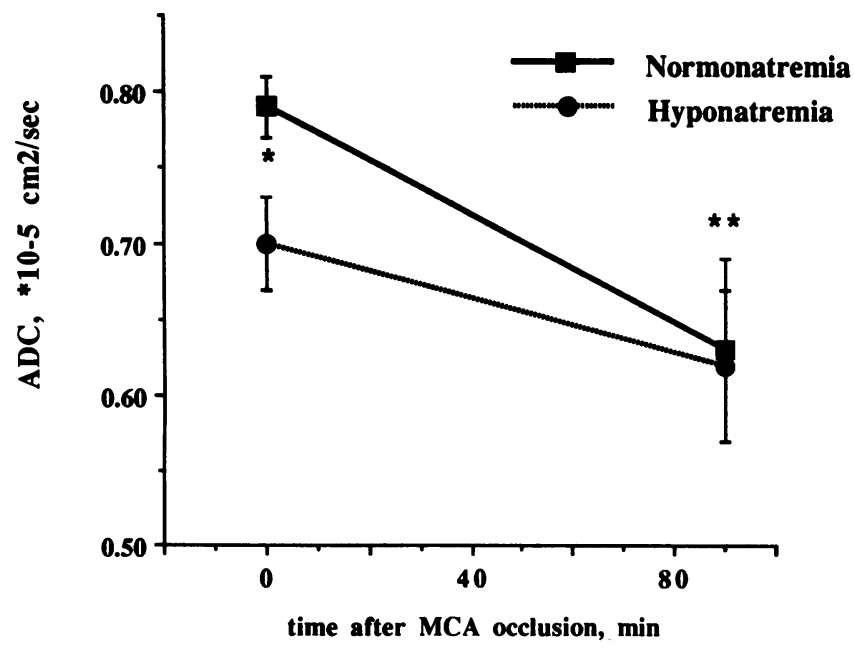

Figure 3. Arithmetic calculated averages of the ADC were obtained from regions of interest in cortex of normonatremic and hyponatremic, ischemic, and hyponatremic/ischemic brains. The ADC after hyponatremia alone was significantly lower than the value of normonatremic. ${ }^{*} P<0.03$ vs. control. The ADC after ischemia alone, or after ischemia plus hyponatremia, was significantly lower than the value in both hyponatremia alone and in normal brain synaptosomes after ischemia alone or ischemia plus hyponatremia. ${ }^{* *} P<0.001$ vs. control. Data are shown as mean \pm SE. for sodium is inhibited by ouabain (12). To determine the transport activity of $\mathrm{Na}^{+}-\mathrm{K}^{+}$-ATPase, we first measured uptake of ${ }^{86} \mathrm{Rb}$ by synaptosomes in uptake media that did not contain ouabain. In parallel experiments, we measured ${ }^{86} \mathrm{Rb}$ uptake by synaptosomes when uptake media did contain ouabain. Subtraction of the value obtained with ouabain from that obtained without ouabain gives the ouabain-sensitive component of potassium uptake and represents the uptake by the $\mathrm{Na}^{+}-\mathrm{K}^{+}$-ATPase pump in synaptosomes. Such studies on sodium/potassium transport via $\mathrm{Na}^{+}-\mathrm{K}^{+}$-ATPase could only be carried out in vitro, because ouabain, a polar compound, does not readily cross the blood-brain barrier (32), and systemic administration of ouabain in amounts necessary to inhibit brain $\mathrm{Na}^{+}-\mathrm{K}^{+}$-ATPase activity in vivo would seriously impair cardiac function.

The value for potassium uptake in synaptosomes from normal tissue was $9.14 \pm 0.47 \mathrm{nmol} / \mathrm{mg}$ protein per $5 \mathrm{~min}$. The corresponding value of potassium uptake with ouabain in the reaction mixture was $3.12 \pm 0.27 \mathrm{nmol} / \mathrm{mg}$ protein per $5 \mathrm{~min}$. Thus, the control value for ouabain-sensitive potassium uptake, i.e., the activity of $\mathrm{Na}^{+}-\mathrm{K}^{+}$-ATPase to transport potassium (Fig. 5), was $6.03 \pm 0.33 \mathrm{nmol} / \mathrm{mg}$ protein per $5 \mathrm{~min}$. In cats with hyponatremia, ouabain-sensitive $\mathrm{Na}^{+}-\mathrm{K}^{+}$-ATPase transport activity, calculated as the difference of potassium uptake without ouabain $(11.44 \pm 0.85 \mathrm{nmol} / \mathrm{mg}$ protein per 5 min) minus uptake with ouabain $(2.78 \pm 0.41 \mathrm{nmol} / \mathrm{mg}$ protein per $5 \mathrm{~min}$ ), was increased to $8.68 \pm 0.70 \mathrm{nmol} / \mathrm{mg}$ protein per $5 \mathrm{~min}$, significantly greater than the value for synaptosomes from control tissue $(P<0.001)$. In synaptosomes isolated from normonatremic ischemic tissue, ouabain-sensitive $\mathrm{Na}^{+}$. $\mathrm{K}^{+}$-ATPase activity, calculated as the difference of potassium uptake without ouabain $(5.77 \pm 0.35 \mathrm{nmol} / \mathrm{mg}$ protein per 5 min) minus uptake with ouabain $(2.39 \pm 0.30 \mathrm{nmol} / \mathrm{mg}$ protein per $5 \mathrm{~min}$ ), was $3.38 \pm 0.26 \mathrm{nmol} / \mathrm{mg}$ protein per $5 \mathrm{~min}$, significantly less than either the control or hyponatremic values $(P<0.001)$. When ischemia was superimposed upon hyponatremia, the values of potassium uptake without and with 

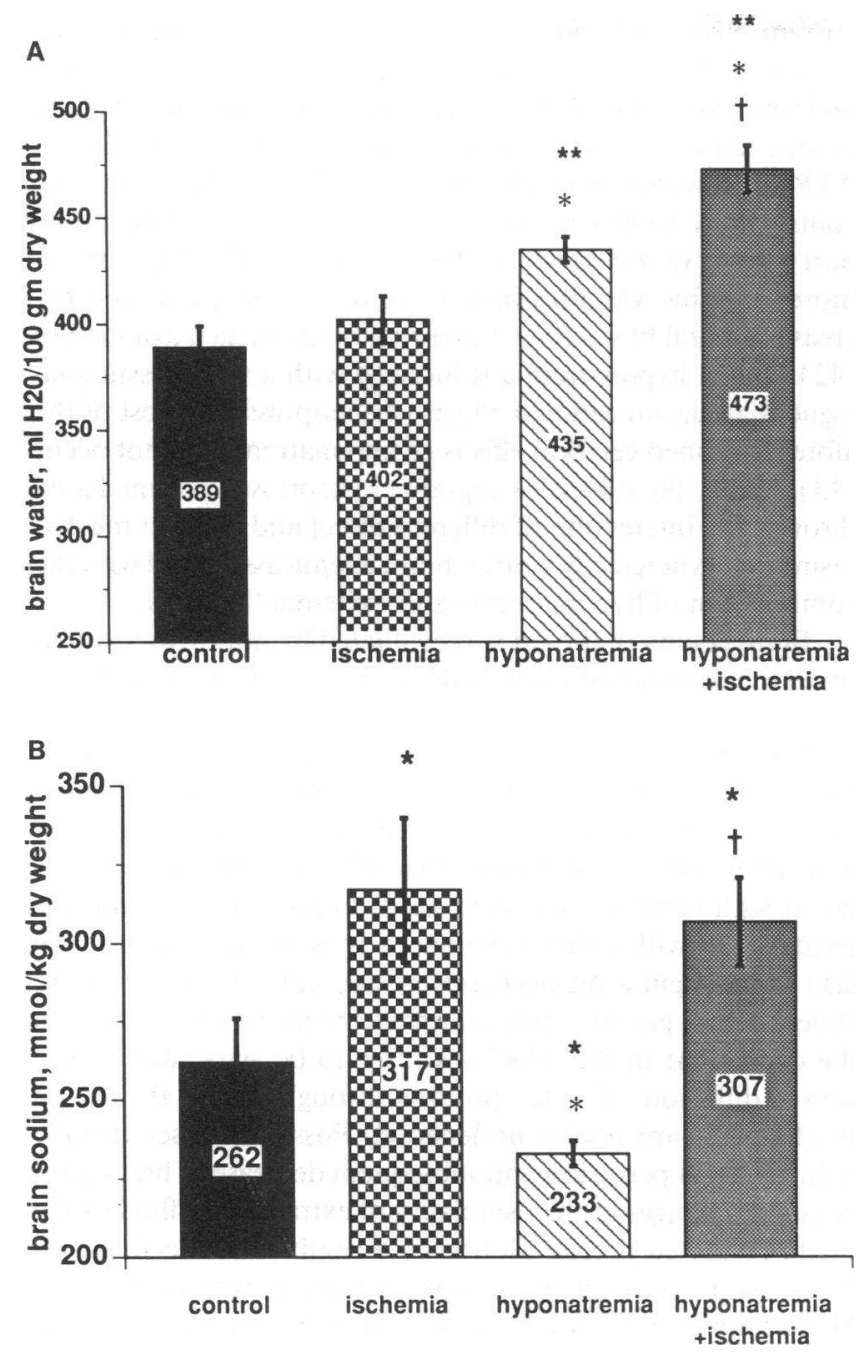

Figure 4. Water and sodium content in normal, ischemic, hyponatremic, and hyponatremic ischemic brain (gray matter) of tissues. $(A)$ Brain water content. $(B)$ Brain sodium content. ${ }^{*} P<0.05$ vs. control. ${ }^{\star \star} P<0.01$ vs. control. ${ }^{*} P<0.025$ vs. ischemia. ${ }^{\dagger} P<0.01$ vs. hyponatremia without ischemia. Both water and sodium content were measured in gray matter of cat brain, using previously described methods. Data are shown as mean \pm SE.

ouabain in the reaction mixture were $5.19 \pm 0.80$ and $1.24 \pm 0.17 \mathrm{nmol} / \mathrm{mg}$ protein per $5 \mathrm{~min}$, respectively. Thus, the ouabain-sensitive transport $\mathrm{Na}^{+}-\mathrm{K}^{+}$-ATPase activity was $3.95 \pm 0.75 \mathrm{nmol} / \mathrm{mg}$ protein per $5 \mathrm{~min}$, significantly lower than the value in cats with either hyponatremia alone, or in synaptosomes from normal cat brain $(P<0.001)$ (Fig. 5).

Veratridine-stimulated sodium uptake in cat brain synaptosomes. Next, we investigated sodium uptake via veratridinestimulated sodium channels, which is a non-energy-requiring pathway. Veratridine is an alkaloid that selectively increases resting membrane permeability to sodium via voltage-sensitive sodium channels (33). The control value of veratridine-stimulated sodium uptake was $2.64 \pm 0.19 \mathrm{nmol} / \mathrm{mg}$ protein per 5 $\mathrm{min}$. Ischemia alone resulted in a significant decrease of sodium uptake via this pathway, to $1.5 \pm 0.09 \mathrm{nmol} / \mathrm{mg}$ protein per $5 \mathrm{~min},(P<0.002$ vs. normal $)$. In hyponatremic animals, veratridine-stimulated synaptosomal sodium uptake, although lower than in controls, was not significantly different
$(2.41 \pm 0.25 \mathrm{nmol} / \mathrm{mg}$ protein per $5 \mathrm{~min} ; P>0.05)$ (Fig. 6). However, the value was significantly higher than after ischemia $(P<0.002)$. In animals with hyponatremia plus ischemia, veratridine-stimulated sodium uptake was also significantly higher $(2.28 \pm 0.24 \mathrm{nmol} / \mathrm{mg}$ protein per $5 \mathrm{~min} ; P<0.002)$ than in cats with ischemia only.

Synaptosomal amiloride-sensitive sodium uptake. Amiloride-sensitive sodium uptake primarily measures an uptake by the sodium/hydrogen exchanger (25). The control value for amiloride-sensitive sodium uptake was $0.29 \pm 0.03 \mathrm{nmol} / \mathrm{mg}$ protein per $5 \mathrm{~min}$. In animals with hyponatremia without ischemia, the amiloride-sensitive sodium uptake $(0.23 \pm 0.04$ $\mathrm{nmol} / \mathrm{mg}$ protein per $5 \mathrm{~min}$ ) was significantly less than the control value $(P<0.05)$. With ischemia alone, the amiloridesensitive sodium uptake was $0.28 \pm 0.06 \mathrm{nmol} / \mathrm{mg}$ protein per 5 $\min (P>0.05$ vs. control $)$. When ischemia was added to the hyponatremia, the amiloride-sensitive sodium uptake $(0.28 \pm 0.036 \mathrm{nmol} / \mathrm{mg}$ protein $)$ was not significantly different from either the control or the hyponatremic value $(P>0.05)$ (Fig. 7).

\section{Discussion}

The results of this study demonstrate that the combined effects of two metabolic encephalopathies, hyponatremia plus hypoxic hypoxia, results in $100 \%$ mortality, whereas neither type of metabolic encephalopathy by itself is associated with a mor-

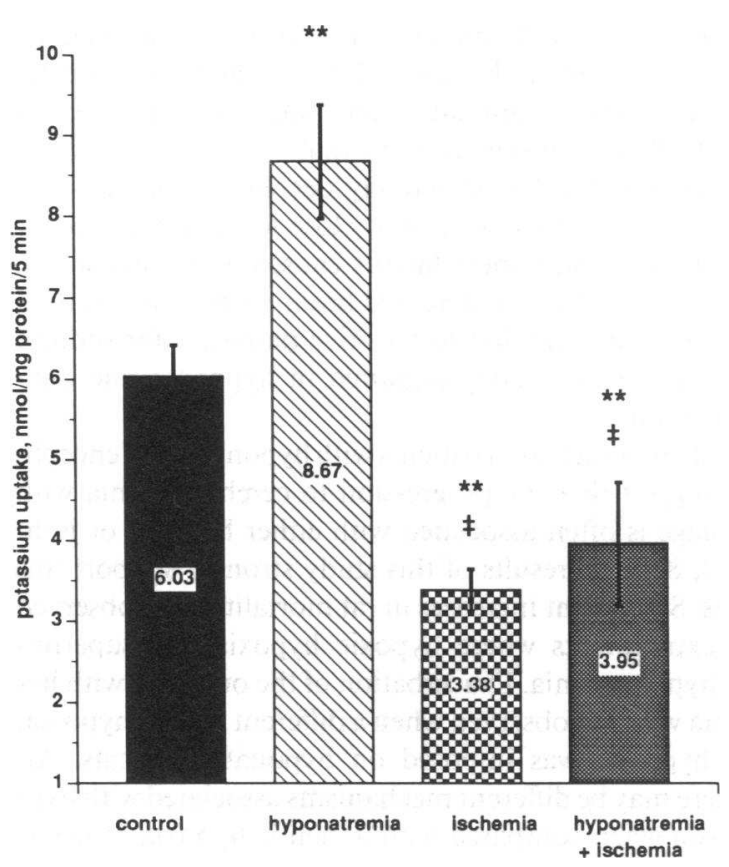

Figure 5. Effects of ischemic hypoxia, hyponatremia, and hyponatremia combined with ischemic hypoxia on the transport activity of synaptosomal $\mathrm{Na}^{+}-\mathrm{K}^{+}$-ATPase. Transport activity of synaptosomal $\mathrm{Na}^{+}-\mathrm{K}^{+}$-ATPase is shown as the mean of the ${ }^{86} \mathrm{Rb}$ uptake with ouabain $(2.5 \mathrm{mM})$ subtracted from that without ouabain in a parallel experiment. Preequilibrium media contains (in $\mathrm{mM}$ ) $\mathrm{NaCl}, 150$; $\mathrm{MgCl}_{2}$, 1; Hepes-Tris, 5; pH 7.40. Uptake media contains (in $\mathrm{mM}$ ) choline chloride, $140 ; \mathrm{MgCl}_{2}$, 5; EGTA, 0.2; KCl, 1; Hepes-Tris, 5; pH 7.40. ${ }^{\star \star} P<0.001$ vs. control. ${ }^{\ddagger} P<0.01$ vs. hyponatremia without ischemia. Data are shown as mean $\pm \mathrm{SE}$. 


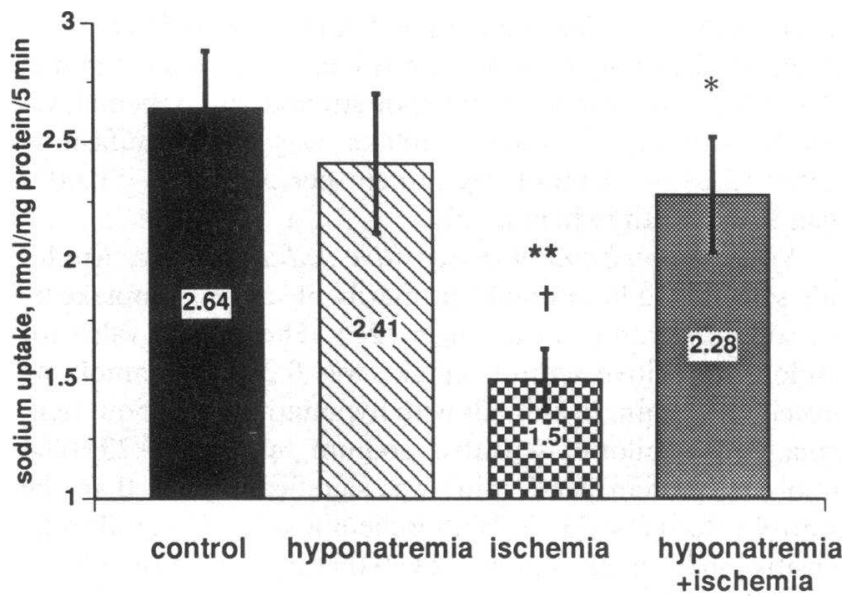

Figure 6. Effect of ischemic hypoxia, hyponatremia, and hyponatremia combined with ischemic hypoxia on the veratridine-stimulated sodium uptake. The mean of the ${ }^{22} \mathrm{Na}$ uptake without veratridine- $\mathrm{HCl}$ subtracted from that with veratridine- $\mathrm{HCl}(50 \mu \mathrm{M})$ in a parallel experiment is shown. Preequilibrium media contains (in $\mathrm{mM}$ ) $\mathrm{KCl}, 50$; $\mathrm{MgCl}_{2}, 1$; Hepes-Tris, $5 ; \mathrm{pH}$ 7.40. Uptake media contains (in mM) choline chloride, 140; $\mathrm{MgCl}_{2}$, 5; EGTA, $0.2 ; \mathrm{NaCl}, 1$; Hepes-Tris, 5; pH 7.40. ${ }^{* \star} \mathbf{P}<0.002$ vs. control. ${ }^{*} P<0.002$ vs. ischemia. ${ }^{\dagger} P<0.002$ vs. hyponatremia without ischemia. Data are shown as mean $\pm \mathrm{SE}$.

tality rate $>25 \%$. A likely explanation for the increased mortality appears to be a failure of homeostatic brain ion transport. Animals with hyponatremia plus ischemic hypoxia are unable to adapt to the hyponatremia, which is clearly manifested by increases in cell water and sodium (Fig. 4, $A$ and $B$ ). Ischemic hypoxia not only eliminated the adaptive increase of $\mathrm{Na}^{+}-\mathrm{K}^{+}$-ATPase transport activity that was initiated by hyponatremia (Fig. 5), but it actually decreased the transport activity to levels below normal and close to those induced by ischemia. In aggregate, these factors caused a net increase in brain sodium, resulting in increased brain edema. In addition, the veratridine- and amiloride-sensitive pathways for sodium transport were also severely impaired in hyponatremic ischemic brain tissue.

Clinical observations in patients with hyponatremic encephalopathy suggest that the progression to cerebral edema with brain damage is often associated with either hypoxia or ischemia $(3,7,8)$. The results of this study strongly support this hypothesis. Significant increases in rat mortality were observed in those experiments where hypoxic hypoxia was superimposed on hyponatremia. Exacerbation of the outcome with hyponatremia was also observed when a different type of hypoxia, ischemic hypoxia, was imposed on hyponatremic cats. Although there may be different mechanisms associated with hypoxic hypoxia when compared with ischemic hypoxia, it seems apparent that both types of hypoxia decrease the effectiveness of the compensatory changes by which the brain adapts to hyponatremia. Other systemic and cerebral effects of hypoxia may also be important in the evolution of hyponatremic brain damage. Hypoxia is a major stimulus for increased secretion of arginine vasopressin $(34,35)$. Vasopressin can directly increase water movement into the brain (36), and thus worsen the brain edema associated with hyponatremia. In the vast majority of hyponatremic patients, blood levels of vasopressin are elevated $(35,37,38)$. This fact suggests the relevance of the current model of hyponatremia (vasopressin plus water) used in this study. In the presence of ischemic hypoxia, increased arginine vasopressin is secreted, which acts to further increase brain edema (39). Vasopressin decreases brain production of ATP and lowers brain intracellular $\mathrm{pH}(40,41)$, which may be contributory factors to the impaired $\mathrm{Na}^{+}-\mathrm{K}^{+}$-ATPase transport activity observed with ischemic hypoxia (Fig. 5). Furthermore, arginine vasopressin may increase vasospasm and decrease cerebral blood flow, impairing brain oxygen availability (42). When hyponatremia is induced with a vasopressin analogue that has no cerebral effects (desmopressin), most of the aforementioned cerebral effects of hyponatremia do not occur (43). Thus, the effects of arginine vasopressin are mediated through the interaction of different direct and indirect mechanisms that synergically worsen brain edema associated with the combination of hyponatremia and ischemia/hypoxia.

Brain edema in the cat was evaluated by noninvasive highspeed echo-planar diffusion MRI, and by measuring water content of the cerebral cortex (gray matter). Both methods delineated brain edema associated with either ischemia, hyponatremia, or a combination of both. Brain water content increased with either hyponatremia or ischemia, although the increase was larger with hyponatremia. When hyponatremia was combined with ischemia, the increase of brain water content was greater than with either ischemia or hyponatremia alone. We also found significant decreases of the ADC in each of these experimental groups when compared with control. Although the decrement in the ADC is known to be associated with a slower diffusion of water protons through tissue, the actual mechanisms are poorly understood. Possible causes include reduced brain perfusion and subsequent decrease in brain temperature, changes in the osmolality of extracellular fluid of the brain, restricted proton motion as a result of intracellular influx of water, and changes in membrane permeability (17). Microdialysis application of $N$-methyl-D-aspartate or glutamate to rat brain has been shown to result in a decrease of the ADC, concomitant with a shift of water from extracellular to intracellular space (32). It has been suggested $(17,19,44)$ that

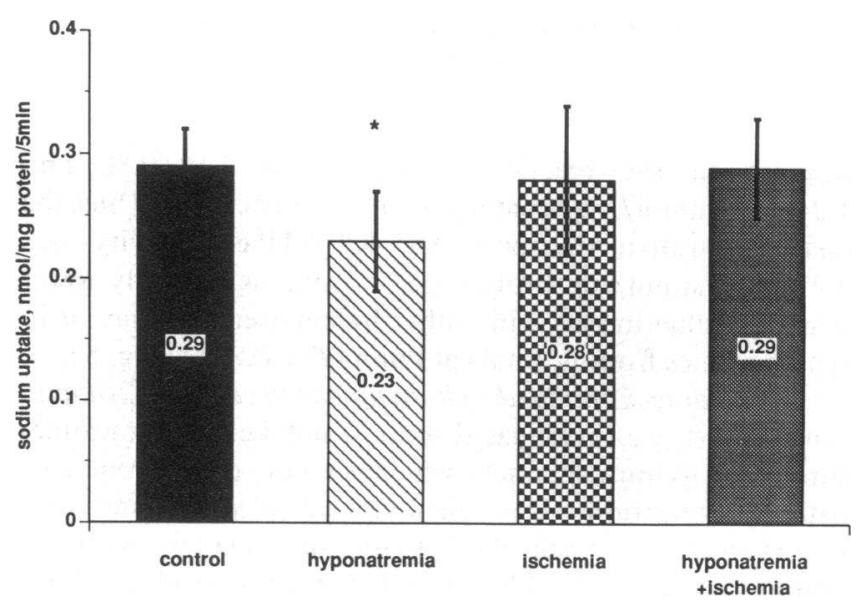

Figure 7. Effect of ischemic hypoxia, hyponatremia, and hyponatremia combined with ischemic hypoxia on amiloride-sensitive sodium uptake. Preequilibrium media contains (in $\mathrm{mM}$ ) KCl, $150 ; \mathrm{MgCl}_{2}, 1$; Hepes-Tris, 5; pH 7.40. Uptake media contains (in mM) choline chloride, $140 ; \mathrm{MgCl}_{2}$, 5; EGTA, $0.2 ; \mathrm{NaCl}, 1$; tetrodotoxin, $10^{-3}$; Hepes-Tris, $5 ; \mathrm{pH} \mathrm{7.40.}{ }^{*} P<0.05$ vs. control. 
a decline of the ADC is a marker for cytotoxic edema. A maximum decline would be expected in areas where there was severely impaired cerebral blood flow, such as ischemic tissue. Our data reveal a significant decrease of the ADC induced by ischemia, in agreement with previous observations $(17,20)$. Decreased neuronal transport of sodium/potassium by the $\mathrm{Na}^{+}-\mathrm{K}^{+}$-ATPase system after ischemic hypoxia appears to be one of the major factors contributing to this decrease (Fig. 1 $A$ ). Hyponatremia also resulted in a lesser, but still significant, decrease of the ADC. This is an interesting observation, because less profound decreases in the ADC indicate a net osmotic shift of water into the brain, including shifts to both intracellular and extracellular compartments. Less profound decreases in the ADC after hyponatremia can also denote a dynamic intra/extracellular water exchange, because of the activation of mechanisms participating in regulatory volume decrease, such as cell membrane pumps.

Adaptation of the brain to hyponatremia involves interaction between efflux of osmotically active cations and a gain of tissue water (10). Loss of brain sodium as an initial adaptive response to hyponatremia was observed in this study, and has previously been reported $(10,45)$. However, when ischemia was added to hyponatremia, there was an actual elevation of brain sodium. Thus, ischemia appeared to eliminate one of the major adaptive mechanisms whereby the brain can adapt to hyponatremia. To further test this hypothesis, we evaluated transport activity of osmotically active cations (sodium and potassium) in neuronal (synaptosomal) membranes. With hyponatremia, there was an increase in $\mathrm{Na}^{+}-\mathrm{K}^{+}$-ATPase transport activity, resulting in net sodium extrusion. However, with ischemic hypoxia, there was a decrease of the $\mathrm{Na}^{+}-\mathrm{K}^{+}$-ATPase transport activity, regardless of the serum sodium level. Activation of sodium extrusion via $\mathrm{Na}^{+}-\mathrm{K}^{+}$-ATPase seems to be one of the major mechanisms contributing to the volume regulatory decrease observed with hyponatremia. Although we did not measure the content of high-energy phosphates in this study, maintenance of functional activity of $\mathrm{Na}^{+}-\mathrm{K}^{+}$-ATPase indirectly indicates availability of ATP in the hyponatremic state (Fig. 5). The decrease of $\mathrm{Na}^{+}-\mathrm{K}^{+}$-ATPase activity with ischemic hypoxia is probably secondary to reduction of intracellular ATP because of decreased cerebral oxygen availability. The level of hypoxic hypoxia in this study (arterial pO $\mathrm{O}_{2}, 35 \mathrm{~mm}$ $\mathrm{Hg}$ ) would not ordinarily result in a decrement of brain ATP (13). However, a combination of simultaneous metabolic insults, including vasopressin administration, has been shown to decrease brain ATP at comparable levels of arterial $\mathrm{pO}_{2}(13$, 41 ). Failure to extrude sodium from neurons when ischemia is superimposed upon hyponatremia results in more severe edema. Whereas either hyponatremia or a brief ischemic episode might be tolerated without irreversible changes, the combination of hyponatremia plus ischemic hypoxia may lead to permanent brain damage (3).

A significant decrease of sodium uptake via veratridinestimulated sodium channels was found after ischemia. Changes in veratridine-stimulated sodium uptake may result from multiple factors, including changes in membrane potential, membrane permeability for sodium, or changes in size and/or number of opened channels. Ischemia could affect membrane potential, causing depolarization and increasing inward movement of sodium. The veratridine-stimulated sodium uptake in synaptosomes from hyponatremic brain tissue was not significantly different from normal. However, the combination of hyponatremia and ischemia was associated with a sodium uptake significantly higher than that induced by ischemia alone. Our data do not provide information as to the mechanisms that might be involved in the elevated sodium uptake observed after hyponatremia plus ischemia compared with ischemia alone. However, the net result would be an increase in net intake of sodium via veratridine-stimulated sodium channels, which further contributes to brain edema.

We also assessed sodium transport via the $\mathrm{Na}^{+} / \mathrm{H}^{+}$exchanger (amiloride-sensitive sodium uptake), which is important for regulation of cell $\mathrm{pH}$, intracellular sodium concentration, and cell volume in many mammalian systems (46). We found a significant decrease of the sodium uptake in synaptosomes from hyponatremic animals. Decreased sodium influx into the brain can serve to initiate the regulatory volume decrease, in spite of possible intracellular acidosis, which has been reported in hyponatremic rats (40).

Based on these data, it appears that ischemic hypoxia severely impairs the brain's adaptive mechanisms during hyponatremia: the $\mathrm{Na}^{+}-\mathrm{K}^{+}$-ATPase system, and the veratridine- and amiloride-sensitive pathways for sodium transport. The crucial factor by which hypoxia leads to increased brain damage and impaired brain adaptation in hyponatremic encephalopathy is the reduction in cerebral oxygen availability. Other studies have demonstrated: $(a)$ hyponatremia can result in reduced cerebral blood flow (ischemia) $(11,47)$; $(b)$ patients with hyponatremic encephalopathy have systemic hypoxemia $(3,7)$ $(8)$; and $(c)$ the neuropathology of hyponatremic encephalopathy is similar to hypoxic brain damage $(8,9,48)$. While this study provides no direct evidence for possible deleterious effects of hypoxia in hyponatremic humans, it does indicate that hypoxia seriously impairs brain adaptation in experimental hyponatremia, and may be an important comorbid factor in the morbidity associated with hyponatremic encephalopathy $(3,7,8)$.

\section{Acknowledgments}

This work was supported by grant RO1 AG-08575 from the National Institute on Aging, Department of Health and Human Services (Bethesda, MD), by the Research Service of the Veterans Affairs Medical Center (San Francisco, CA), and by a grant from Nycomed Salutar Inc. (Sunnyvale, CA).

\section{References}

1. Fraser, C. L., and A. I. Arieff. 1993. Metabolic encephalopathy associated with water, electrolyte, and acid-base disorders. In Clinical Disorders of Fluid and Electrolyte Metabolism. R. G. Narins, M. H. Maxwell, and C. R. Kleeman, editors, 5th ed. McGraw-Hill Inc., New York. 1258-1322.

2. Fraser, C. L., and A. I. Arieff. 1985. Hepatic encephalopathy. N. Engl. J. Med. 313:865-873.

3. Ayus, J. C., J. M. Wheeler, and A. I. Arieff. 1992. Postoperative hyponatremic encephalopathy in menstruant women. Ann. Intern. Med. 117:891-897.

4. Ginsberg, M. D. 1979. Delayed neurological deterioration following hypoxia. Adv. Neurol. 26:21-44.

5. Ayus, J. C., J. J. Olivero, and J. P. Frommer. 1982. Rapid correction of severe hyponatremia with intravenous hypertonic saline solution. Am. J. Med. $72: 43-48$.

6. Griggs, R. C., and A. I. Arieff. 1992. Hypoxia and the central nervous system. In Metabolic Brain Dysfunction in Systemic Disorders. R. C. Griggs and A. I. Arieff, editors, Little, Brown and Company, Boston. 39-54.

7. Arieff, A. I., J. C. Ayus, and C. L. Fraser. 1992. Hyponatraemia and death or permanent brain damage in healthy children. Br. Med. J. 304:1218-1222.

8. Tien, R., A. I. Arieff, W. Kucharczyk, A. Wasik, and J. Kucharczyk. 1992. 
Hyponatremic encephalopathy: is central pontine myelinolysis a component? Am. J. Med. 92:513-522.

9. Krigman, M. R., and T. W. Bouldin. 1983. Oxygen deficiency: brain hypoxia and ischemia. In The Clinical Neurosciences: Neuropathology. S. S. Schochet, Jr., editor. R. N. Rosenberg, series editor. Churchill-Livingstone, Inc. New York. 496-561.

10. Melton, J. E., C. S. Patlak, K. D. Pettigrew, and H. F. Cserr. 1987. Volume regulatory loss of $\mathrm{Na}, \mathrm{Cl}$, and $\mathrm{K}$ from rat brain during acute hyponatremia. Am.J. Physiol. 252 (Renal Fluid Electrolyte Physiology. 21):F661-F669.

11. Rosomoff, H. L., and F. T. Zugibe. 1963. Distribution of intracranial contents in experimental edema. Arch. Neurol. 9:36-44.

12. Fraser, C. L., and P. Sarnacki. 1989. $\mathrm{Na}^{+}-\mathrm{K}^{+}-$ATPase pump function in male rat brain synaptosomes is different from that of females. Am. J. Physiol. 257 (Endocrinology Metabolism. 20):E284-E289.

13. Ishige, N., L. H. Pitts, L. Pogliani, T. Hashimoto, M. C. Nishimura, H. M. Bartkowski, and T. L. James. 1987. The effects of hypoxia on traumatic brain injury in rats: Part 2. Changes in high energy phosphate metabolism. Neurosurgery (Baltimore). 20:854-858.

14. Ayus, J. C., R. Krothapalli, D. L. Armstrong, and H. J. Norton. 1989. Symptomatic hyponatremia in rats: effect of treatment on mortality and brain lesions. Am. J. Physiol. 257 (Renal Fluid Electrolyte Physiology. 26):F18-F22.

15. Arieff, A. I., and H. Graf. 1987. Pathophysiology of type A hypoxic lactic acidosis in dogs. Am. J. Physiol. 253 (Endocrinology Metabolism. 16):E271E276.

6. Kucharczyk, J., J. Mintorovitch, M. E. Moseley, H. S. Asgari, R. Sevick, N. Derugin, and D. Norman. 1991. Ischemic brain edema is reduced by a novel calcium and sodium channel entry blocker. Radiology. 179:221-227.

17. Moseley, M. E., J. Kucharczyk, J. Mintorovitch, Y. Cohen, J. Kurhanewicz, N. Derugin, H. Asgari, and D. Norman. 1990. Diffusion-weighted MR imaging of acute stroke: correlation with T2-weighted and magnetic susceptibility-enhanced MR imaging in cats. American Journal of Neuroradiology. 11:423429.

18. Stejskal, E. O., and J. E. Tanner. 1965. Spin diffusion measurements spin-echoes in the presence of a time-dependent field gradient. J. Chem. Phys 42:288-292.

19. Sevick, R. J., F. Kanda, J. Mintorovitch, A. I. Arieff, J. Kucharczyk, J. S. Tsuruda, D. Norman, and M. E. Moseley. 1992. Cytotoxic brain edema: Assessment using diffusion-weighted MR imaging. Radiology. 185:687-690.

20. Roberts, T. P. L., Z. S. Vexler, N. Duregin, M. E. Moseley, and J. Kucharczyk. 1993. High-speed MR imaging of ischemic brain injury following partial stenosis of the middle cerebral artery. J. Cereb. Blood Flow Metab. In press

21. LeBihan, D. 1990. Magnetic resonance imaging of perfusion. Magn. $R e$ son. Med. 14:283-292.

22. Kucharczyk, J., W. Chew, N. Derugin, and M. E. Moseley. 1989. Nicardipine reduces ischemic brain injury. An in vivo magnetic resonance imaging/ spectroscopy study in cats. Stroke. 20:268-274.

23. Fraser, C. L., P. Sarnacki, and A. I. Arieff. 1985. Abnormal sodium transport in synaptosomes from brain of uremic rats. J. Clin. Invest. 75:2014-2023.

24. Keen, P., and T. D. White. 1976. The permeability of pinched off nerve endings to sodium, potassium and chloride and the effects of gramiciden. $J$. Neurochem. 18:1097-1103.

25. Kanda, F., P. Sarnacki, and A. I. Arieff. 1992. Atrial natriuretic peptide inhibits the amelioride-sensitive sodium-hydrogen exchanger in rat brain. $\mathrm{Am}$. J. Physiol. 263 (Regulatory Integrative Comp. Physiol. 32):R279-R283.

26. Lowry, O. H., A. L. Rosenberg, A. L. Farr, and R. J. Randall. 1951. Protein measurements with Folin-phenol reagent. J. Biol. Chem. 193:265-275.

27. Arieff, A. I., C. R. Kleeman, A. Keushkerian, and H. Bagdoyan. 1973. Studies on mechanisms of cerebral edema in diabetic comas. Effects of hypergly cemia and rapid lowering of plasma glucose in normal rabbits. J. Clin. Invest. 52:571-583.

28. Browner, W. S., D. Black, T. B. Newman, and S. B. Hulley. 1988. Estimat- ing sample size and power. In Designing Clinical Research. S. B. Hulley and S. R. Cummings, editors, Williams \& Wilkins Co., Baltimore. 139-150.

29. Hulley, S. B., and S. R. Cummings. 1988. Appendix 13.A, In Designing Clinical Research, S. B. Hulley and S. R. Cummings, editors. Williams \& Wilkins Co., Baltimore. 215-217.

30. Rafalowska, U., M. Erecinska, and D. F. Wilson. 1980. The effects of acute hypoxia on synaptosomes from rat brain. J. Neurochem. 35:1160-1165.

31. Rafalowska, U., M. Erecinska, and D. F. Wilson. 1980. Energy metabolism in rat brain synaptosomes from nembutal-anesthetized and nonanesthetized animals. J. Neurochem. 34:1380-1386.

32. Benveniste, H., L. W. Hedlund, and G. A. Johnson. 1992. Mechanism of detection of acute cerebral ischemia in rats by diffusion-weighted magnetic resonance microscopy. Stroke. 23:746-754.

33. Gill, D. L. 1982. Sodium channel, sodium pump, and sodium-calcium exchange activities in synaptosomal plasma membrane vesicles. J. Biol. Chem. 257:10986-10990.

34. Heyes, M. P., M. O. Farber, F. Manfredi, D. Robertshaw, M. Weinberger, N. Fineberg, and G. Robertson. 1982. Acute effects of hypoxia on renal and endocrine function in normal humans. Am. J. Physiol. 243 (Regulatory Integrative Comp. Physiol. 12):R265-R270.

35. Schrier, R. A., and T. Berl. 1979. Osmotic and nonosmotic control of vasopressin release. Am. J. Physiol. 236:F321-F332.

36. Rosenberg, G. A., E. Estrada, and W. T. Kyner. 1990. Vasopressin-induced brain edema is mediated by the V1 receptor. Adv. Neurol. 52:149-154.

37. Anderson, R. J., H. M. Chung, R. Kluge, and R. W. Schrier. 1985. Hyponatremia: a prospective analysis of its epidemiology and the pathogenetic role of vasopressin. Ann. Intern. Med. 102:164-168.

38. Fraser, C. L., and A. I. Arieff. 1990. Water metabolism and its disorders. In The Metabolic and Molecular Basis of Acquired Disease. R. D. Cohen, B. Lewis, K. G. M. M. Alberti, and A. M. Denman, editors, W. B. Saunders Company, Philadelphia. 1002-1039.

39. Dickinson, L. D., and A. L. Betz. 1992. Attenuated development of ischemic brain edema in vasopressin-deficient rats. J. Cereb. Blood Flow Metab. 12:681-690.

40. Adler, S., and V. Simplaceanu. 1989. Effect of acute hyponatremia on rat brain $\mathrm{pH}$ and rat brain buffering. Am. J. Physiol. 256 (Renal Fluid Electrolyte Physiology. 25):F113-F119.

41. Fraser, C. L., J. Kucharczyk, A. I. Arieff, C. Rollin, P. Sarnacki, and D. Norman. 1989. Sex differences result in increased morbidity from hyponatremia in female rats. Am. J. Physiol. 256 (Regulatory Integrative Comp. Physiol. 25):R880-R885.

42. Delgado, T. J., M. A. R. Arbab, J. Warberg, and N. A. Svendgaard. 1988 The role of vasopressin in acute cerebral vasospasm. J. Neurosurg. 68:266-273

43. Arieff, A. I., E. Kozniewska, T. P. L. Roberts, Z. S. Vexler, F. Kanda, and J. Kucharczyk. 1993. Role of vasopressin in brain damage from hyponatremic encephalopathy. In Vasopressin IV. D. Richter, P. Gross, and G. Robertson, editors, John Libbey Eurotext Limited, Montrouge, France. In press.

44. Moseley, M. E., R. Sevick, M. F. Wendland, D. L. White, J. Mintorovitch, H. S. Asgari, and J. Kucharczyk. 1991. Ultrafast magnetic resonance imaging: Diffusion and perfusion. Can. Assoc. Radiol. J. 42:29-37.

45. Arieff, A. I., F. Llach, S. G. Massry, and A. Kerian. 1976. Neurological manifestations and morbidity of hyponatremia: correlation with brain water and electrolytes. Medicine (Baltimore). 55:121-129.

46. Goetz, K. L. 1988. Physiology and pathophysiology of atrial peptides. Am. J. Physiol. 254 (Endocrine Metabolism. 17):E1-E15.

47. Hasan, D., E. F. M. Wijdicks, and M. Vermeulen. 1990. Hyponatremia is associated with cerebral ischemia in patients with aneurysmal subarachnoid hemorrhage. Ann. Neurol. 27:106-108.

48. Fraser, C. L., and A. I. Arieff. 1990. Fatal central diabetes mellitus and insipidus resulting from untreated hyponatremia: a new syndrome. Ann. Intern. Med. 112:113-119. 